Article

\title{
Greta Thunberg and the Generation of Moral Authority: A Systematic Literature Review on the Characteristics of Thunberg's Leadership
}

\author{
Nessica Nässén * and Komalsingh Rambaree \\ Department of Social Work and Criminology, University of Gävle, 80176 Gävle, Sweden; kolsie@hig.se \\ * Correspondence: nessica.nassen@hig.se; Tel.: +46-(73)-8478005
}

check for

updates

Citation: Nässén, N.; Rambaree, K. Greta Thunberg and the Generation of Moral Authority: A Systematic

Literature Review on the

Characteristics of Thunberg's Leadership. Sustainability 2021, 13, 11326. https://doi.org/10.3390/ su132011326

Academic Editors: Virginia Bodolica and Christian Vandenberghe

Received: 30 July 2021

Accepted: 10 October 2021

Published: 13 October 2021

Publisher's Note: MDPI stays neutral with regard to jurisdictional claims in published maps and institutional affiliations.

Copyright: (c) 2021 by the authors. Licensee MDPI, Basel, Switzerland. This article is an open access article distributed under the terms and conditions of the Creative Commons Attribution (CC BY) license (https:// creativecommons.org/licenses/by/ $4.0 /)$.

\begin{abstract}
Numerous efforts have been made by political leaders worldwide to prevent further climate change and develop sustainable solutions. However, due to conflicting political positions and the complex solutions required, attempts to limit climate change have proven largely ineffective. For these reasons, a new kind of environmental change leader is needed to catalyze significant societal transformation. In recent years, Greta Thunberg has become a major spokesperson for environmental issues, mobilizing people worldwide to act against climate change. Utilizing a theoretical framework based on transformational leadership and moral authority, this article discusses, by means of a systematic literature review, the characteristics of Thunberg's leadership. Using the PRISMA protocol, data were collected from various national and international media sources. With the assistance of ATLAS-ti.v.9 Scientific Software Development GmbH, Berlin, Germany, qualitative deductive content analysis was performed to analyze the data. In this review, we discuss how Thunberg embodies five characteristics that are typical of moral authority, thereby becoming a transformational leader who influences the possibility of preventing climate change and promotes more sustainable solutions. This article concludes that it is through the characteristics of moral authority that Greta Thunberg has become a global transformational leader for those defending the natural environment.
\end{abstract}

Keywords: transformational leadership; moral authority; sustainability; transformation

\section{Introduction}

Climate change is doubtless the ultimate challenge of our time. There have already been many notable and adverse changes to the natural environment, such as sea-ice shrinkage, higher sea levels, and more extreme fluctuations of normal weather conditions [1]. Political leaders worldwide have come together to implement measures intended to reduce and/or prevent climate change. One such measure is the Paris Agreement, a legally binding international treaty on climate change, whereby countries collaborate to implement sustainable solutions for keeping global warming below $1.5^{\circ} \mathrm{C}$ [2]. Currently, the general approach to climate change is state-centric, with political leaders attempting to address the problem through different agreements and institutions [3]. However, even if the ecological footprint can be reduced, doing so will take time and require cautious decision-making [3]. Several scholars have drawn attention to the complexity of the negotiation process in the political arena and to the absence of overall leadership as being two major hindrances to efforts to limit climate change [3-6]. Differing beliefs and multidimensional problems relating to climate change pose the question of what kind of leader is required to address the problem most effectively. Scholars of environmental issues stress the importance of political leaders understanding the interaction between humans and the natural environment, emphasizing how people's cultural beliefs concerning the natural environment affect their choices on addressing climate change [6,7]. Arguably, a leader for environmental issues must look beyond the idea of mere sustainability and instead seek critical actions for soci- 
etal transformation [7]. Many thinkers have suggested that transformational leadership is best suited as a potentially effective solution to climate change in various contexts [5,8-10].

Greta Thunberg has become a global spokesperson for nature and the climate [11-13]. With Thunberg as their inspiration, children worldwide have demonstrated on the streets instead of going to school, urging adults-particularly political leaders-to act against climate change [14]. This new generation of young activists now has the world's attention, with Thunberg undeniably their poster-child [15-18]. The influence and attention she has gained did not come about through financial backing, a celebrity background, or political achievements [19]. Rather, Thunberg captured the world's attention through moral authority and charisma [20]. This young climate activist may be the type of transformational leader we need in order to demand and catalyze change. Countless articles have examined Thunberg, some acknowledging her efforts and achievements to promote sustainability [21-24], others accusing her of devaluing democracy, blaming her for spreading "fake news" and instigating rebellious behavior in the younger generation $[25,26]$.

This study did not attempt to summarize the accomplishments of Thunberg or to present positive versus negative opinions of her media presence. Rather, its purpose was to contribute to existing research via an alternative approach to considering Thunberg's leadership characteristics. Utilizing a conceptual and theoretical framework based on transformational leadership and moral authority, this study particularly aimed to discuss conceptions of the characteristics of Thunberg's leadership, by means of a systematic review of academic articles and popular journalistic media reports. This study considered the following research questions. RQ1: What kinds of discourses in the media characterize Thunberg's moral authority? RQ2: What personal qualities of Thunberg, as discussed in media discourses, mark her as a transformational leader?

\section{Theoretical Framework}

By applying transformational leadership theory (TL), this study refers to the five typical characteristics of moral authority, as discussed by various scholars [8,9,27-31]. Figure 1 presents the applied theoretical framework, showing different key concepts used in ATLAS-ti.v.9, Scientific Software Development GmbH, Berlin, Germany, as codes during the systematic analysis of the data. The upper part of Figure 1 presents the five identified characteristics of moral authorities: sacrifice, hope, trust, belonging, and courage. The lower part presents the four elements of TL: idealized influence, individualized consideration, intellectual stimulation, and inspirational motivation.

\subsection{Theoretical Framework: Moral Authority}

Moral authority is a complex concept that is difficult to define. Ferrari [29] (p. 29) defines moral authority in terms of having the ability and confidence to identify, with conviction, right and wrong societal behaviors [32]. In addition, Sharer opines that "lack of moral authority in leaders breeds distrust, creates cynicism, and kills initiative. Over time, the lack of strong moral authority in the leadership is fatal" [14] (pp. 74-75). One general assumption is that moral authority inspires hope, giving people the confidence to have and pursue specific goals [29]. Moral authority, from an anthropological perspective, is understood as charisma that is culturally situated and emerges from the desires of people [10]. Regarding moral authority as a process suggests that it is a two-way and interactive dynamic [28]. Thunberg can be considered a moral authority because she does not have the physical power to force her will on people; rather, she can convince people to willingly follow her and to acknowledge her moral principles as the truth [32].

According to traditional leadership theories, such as the "great man" and "traits" theories, people tend to obey leaders to gain rewards, to avoid undesirable consequences, and/or out of a belief that their authority is legitimate [33]. Moral authority, however, is created through the support of followers [27]. There are five characteristics of moral authority that are recurrently addressed by scholars [8,27-30]. These are: sacrifice, i.e., giving up something of value for the shared vision that the result will be worth the effort; 
trust in the leader, whose vision encourages a willingness to follow; courage in standing firm in one's beliefs; hope, so the followers are empowered; and belonging, which creates a sense of being part of something larger. These characteristics were used as sub-headings in the process of analyzing and discussing the present findings.

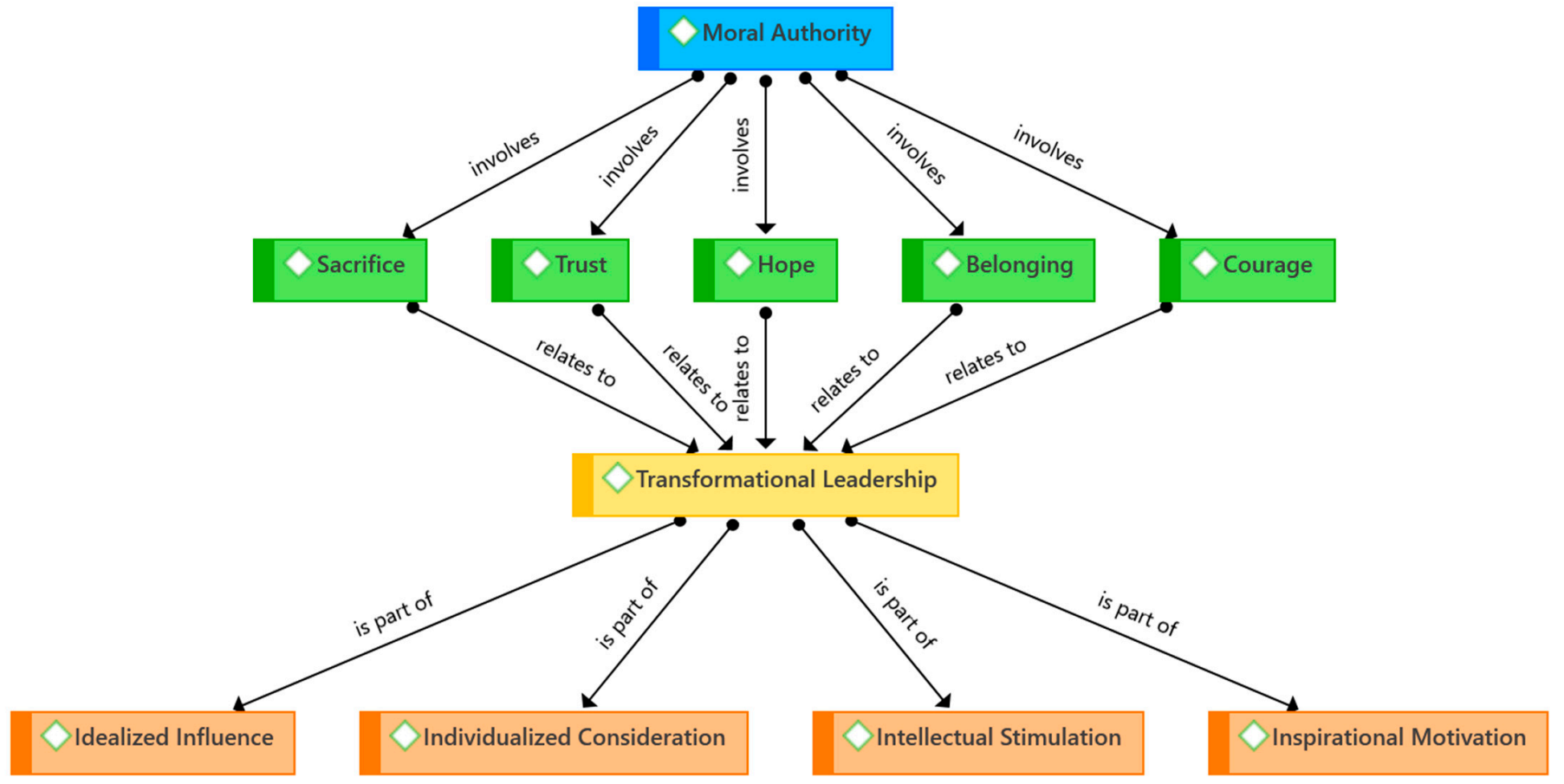

Figure 1. Theoretical framework.

\subsection{Theoretical Framework: Transformational Leadership Theory (TL)}

To understand Thunberg's ability to influence so many people, transformational leadership theory (TL) offered a framework for examining her capacity to persuade people to willingly follow her and to change set behaviors [34]. The success of leadership is related to the behavior of the leader and the needs of the followers [9]. TL requires the ability to engage in a process that transforms and changes followers, emphasizing individual and group values, emotions, and ethics [8]. TL suggests that leaders who possess certain personal traits and have a particular relationship with their followers can achieve the most change $[35,36]$. Furthermore, TL can arguably have an impact at the individual, group, and societal levels, as well as influencing entire cultures [35-37]. There are four subcategories of TL [33]. The first is individualized consideration, referring to a leader's ability to build personal relationships with individuals or groups [38]. This sub-category was used to analyze Thunberg's skill at promoting self-development and her followers' ability to identify with her. Second is intellectual stimulation, emphasizing the leader's ability to persuade people to follow intellectual and rational arguments [34]. Within this context, Thunberg's reliance on science and her identification of sustainable solutions were addressed. She encourages her followers to think like her and to challenge old ways of doing things [10,21-23]. The next component of TL is inspirational motivation, with an emphasis on emotional stimulation. Here, the focus was on Thunberg's strong and evocative language and its impact on people, as well as her ability to share her vision. Finally, we have idealized influence, stressing the importance of leaders leading by example, sacrificing themselves for the sake of their values and mission [34]. This section was applied when analyzing Thunberg as a role model of moral behavior and how she thereby gained respect and trust. According to TL theory, if a leader is successful within these four subcategories, their performance exceeds expectations. 


\section{Materials and Methods}

This article presents and discusses a qualitative systematic literature review, attempting to understand what engendered Thunberg's moral authority, applying TL as a theoretical framework. A qualitative design helped the authors consider the subjective experience of Thunberg's characteristics that enhanced her moral authority [39]. This study applied deductive reasoning, enabling the utilization of pre-existing themes connected to the analytical framework when collecting and analyzing the data [39]. Deductivism was used to support the coding and thematizing of the literature review's contents, with the help of the selected theoretical framework.

The data collection for the study was undertaken in two phases: (1) the systematic identification of empirical data, and (2) screening the data for eligibility. Table 1 shows the process of seeking online data, using the filter "News" (written in either Swedish or English), with specific keywords and phrases connected to the five characteristics of moral authority.

Table 1. Systematic identification of empirical data.

\begin{tabular}{|c|c|c|c|}
\hline No. & Description & & Items Found (Approx.) \\
\hline 1 & Moral authority & $\begin{array}{l}\text { TITLE-ABS-KEY: ((Thunberg Moral authority) OR } \\
\text { (Thunberg Moral) OR (Thunberg Authority) OR } \\
\text { (Thunberg Hope) OR (Thunberg Trust) OR } \\
\text { (Thunberg Sacrifice) OR (Thunberg Courage) OR } \\
\text { (Thunberg Belonging) OR (Thunberg Hope follow) } \\
\text { OR (Thunberg Trust follow) OR (Thunberg Sacrifice } \\
\text { follow) OR (Thunberg Courage follow) OR } \\
\text { (Thunberg Belonging follow) OR (Thunberg } \\
\text { Identity) OR (Thunberg Identity morality) OR } \\
\text { (Thunberg Identity authority)) }\end{array}$ & 6550 \\
\hline 2 & Transform-ational leadership & $\begin{array}{l}\text { TITLE-ABS- KEY: ((Thunberg influence leaders) } \\
\text { (Thunberg influence) OR (Thunberg influence } \\
\text { power) OR (Thunberg influence authority) OR } \\
\text { (Idealized leader) OR (Thunberg idealized) } \\
\text { OR(Intelligence leader) (Thunberg follow) OR } \\
\text { (Thunberg Leader) OR (Thunberg inspiring) OR } \\
\text { (Thunberg Inspiring leader) OR (Thunberg Inspiring } \\
\text { authority) or (Thunberg Transformational leader)) }\end{array}$ & 84 \\
\hline 3 & & 1 AND 2 & 632 \\
\hline 4 & & $\begin{array}{c}3 \text { AND Filters activated: Language (English and } \\
\text { Swedish); Time: } 18 \text { January } 2021 \text { to } 1 \text { May 2022; } \\
\text { Publication type: Academic Article and Journalistic } \\
\text { Article }\end{array}$ & 370 (Duplicates not removed) \\
\hline
\end{tabular}

Data were gathered from public online sources between 18 January 2021 and 1 May 2021. The primary focus of the material was in the summer of 2018 when Thunberg began her climate strike by sitting outside the Swedish parliament every Friday, until the present. The purpose was to systematically review and discuss the characteristics of Thunberg's moral authority. The data predominantly came from popular journalistic literature and peer-reviewed literature from Europe and the United States. Popular journalistic literature was defined as articles in magazines and newspapers that are available to the public and written by both academics and non-academics alike. Such literature is not subject to structured peer review and contains no referencing [19]. The data search in popular journalistic literature identified 354 relevant articles, given the applied restrictions, such as using the filter "news," including only English- and Swedish-language articles, and seeking specific keywords and phrases connected to the characteristics of moral authority. We identified 310 articles from international sources and 44 articles from Swedish sources. The phrase "peer-reviewed literature" refers to academic articles from recognized journals. 
For the peer-reviewed literature search, the Scopus and Web of Science databases were used as search tools. The data identified were used to gain additional knowledge and understanding of the perceptions of Thunberg and her leadership characteristics; this enhanced the ability to generalize, by strengthening the assumptions formed from the popular journalistic literature. The peer-reviewed literature was restricted to Englishlanguage articles that specifically addressed Thunberg. Altogether, the records identified 16 articles meeting the search criteria. The next step in the research process was to screen the data for eligibility. The search results were downloaded and managed according to the PRISMA protocol for organizational and analytical purposes. After the data were screened for duplicates, which were then removed, 286 articles remained from the popular journalistic literature and eight from the peer-reviewed literature. Applying the PRISMA protocol, the authors screened and extracted publication citations for the purposes of removing articles that did not relate to the pre-existing themes connected to the theoretical framework. Data extraction was carried out independently by the first author. This was possible due to PRISMA's various features, such as creating a review, uploading citations, gathering all the reviews in a dashboard, free-text labeling citations, free-text search, and face-based filtering [40].

Next, we extracted articles that did not present any indication of addressing Thunberg as a leader or mentioning her followers. Some scholars argue that the process of extracting articles has no meaningful impact on synthesis findings because a qualitative study, as such, is not trying to present a generalized truth [41]. However, due to the number of articles identified, this process was deemed necessary to narrow down the empirical data. The results of the extraction were compared and double-checked to see if there were any differences in interpretation. After the extraction, 163 full-text popular journalistic articles and seven full-text peer-reviewed articles were identified for eligibility. Thereafter, 115 popular journalistic articles were excluded based on: no appropriate outcomes; irrelevance to the purpose of the study; similarities to other articles; and/or the library being unable to find the article. Of the seven remaining peer-reviewed articles, one was excluded for not being publicly accessible. Ultimately, 48 full-text popular journalistic articles and six peerreviewed articles were included in the qualitative synthesis. Of the popular journalistic articles, 15 were from Swedish magazines, comprising three from Aftonbladet, four from Svenska Dagbladet, three from The Local, and five from Dagens Nyheter. There were 33 articles from international newspapers and magazines: seven from the New York Times, four from The Guardian, five from Fox News, three from the Boston Review, four from the Washington Post, two from the Vancouver Sun, five from QUARTZ, and three from BBC News. Of the six remaining peer-reviewed articles included in the qualitative synthesis, one came from Nature research journals, two from SAGE journals, one from Lancet Planetary Health, and two from The Political Quarterly. Figure 2 presents the PRISMA flow diagram, showing the process of screening the data for eligibility.

The data gathered from online electronic sources were analyzed within the framework of deductive content analysis, a facility available in the ATLAS-ti.9, Scientific Software Development $\mathrm{GmbH}$, Berlin, Germany, qualitative analysis software [39]. In this deductive approach, the data were assigned to ATLAS-ti.9, Scientific Software Development GmbH, Berlin, Germany, for qualitative content analysis, a method often used to systematically analyze written material [42]. The coding frame was based on several prearranged codes and saved to the "List Coding" feature in ATLAS-ti.9, Scientific Software Development $\mathrm{GmbH}$, Berlin, Germany. These pre-existing codes were created in accordance with the analytic framework, i.e., the five characteristics outlining moral authority and the four sub-categories of TL. This was conducted before analyzing the gathered data, in what is referred to as "driven coding." "List coding" allowed the researcher to recognize sections of the gathered data that could be grouped together and linked to prearranged codes [39]. This process of grouping parts of the data is referred to as "quotation" in the ATLAL-ti.9, Scientific Software Development GmbH, Berlin, Germany, whereas Bengtsson [39] refers to this process as open coding. 


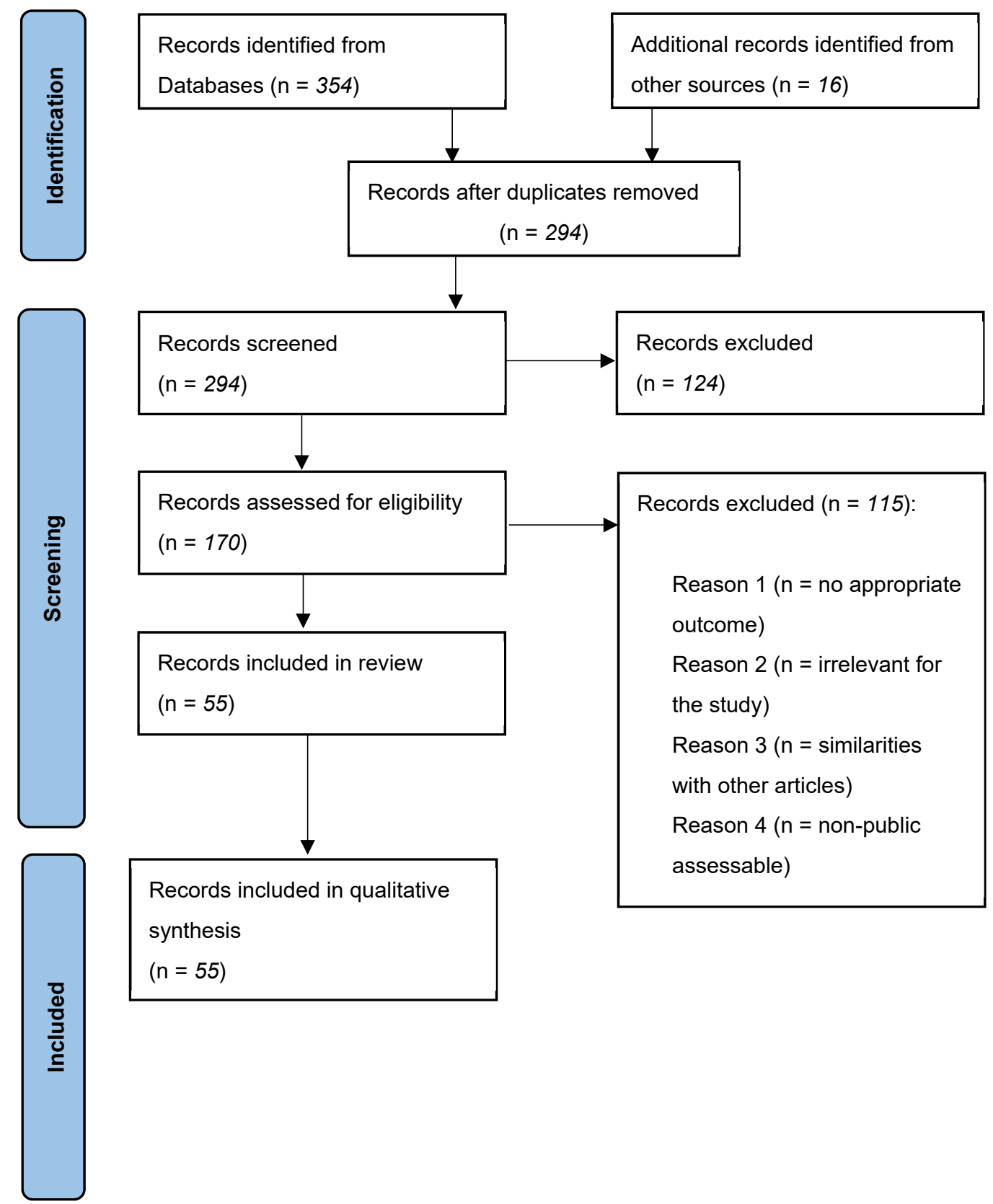

Figure 2. PRISMA flow diagram.

During the data analysis, the researchers began with a manifest deductive qualitative content analysis to discuss the different qualities of leadership that Thunberg possesses and her impact on people. When conducting manifest qualitative content analysis with a deductive approach, researchers tend to seek content that aligns with the pre-existing analytic framework and research questions [39]. In this endeavor, axial coding, the purpose of which is to explore the interrelationships between various data sources, was applied. Here, the relationships between themes were examined, formulated, and classified [39]. Thereafter, latent deductive quality content analysis was conducted to explore the different underlying behaviors of Thunberg and her followers that generated moral authority. Latent deductive quality content analysis enables researchers to find hidden interpretations of the gathered data by applying conceptual lenses and theory-based codes [43]. 


\section{Ethical Considerations}

This study did not require ethical approval because the data collected were previously published materials that are available in the public domain. Bengtsson [39] has stated that defining ethical principles for online data is problematic due to the wide range of online search features and the differing data found on the Internet. In the opinion of Burles and Bally [44], it is crucial to use properly cited original online sources to strengthen the validity of gathered data [44]. It is therefore vital to cite the data accordingly and to differentiate between interpretation and actual statements found in the material. Actual statements from the gathered data are cited using quotation marks in the resulting article. This allows readers to distinguish between actual statements (i.e., manifest content) and the authors' interpretations based on actual statements (i.e., latent content). Moreover, objectivity is always an ethical dilemma in qualitative research [44]. Consequently, qualitative research based on online material can reveal new knowledge of subjective understandings, which may not surface in face-to-face studies. Such an approach also allows for in-depth discussion, examining commonalities and contradictions between the findings and interpretations found in different articles.

\section{Results and Discussion}

The present findings were analyzed in the context of five recurring characteristics of moral authority, utilizing the TL framework. Although these characteristics intertwine and vary in proportion from one leader to another, this study separated them for structural discussion purposes. These leadership characteristics are: sacrifice, trust, courage, hope, and belonging.

\subsection{Sacrifice}

This study identifies several different forms of sacrifice made by Thunberg. First, there are the sacrifices of time, energy, and material comfort. The findings show that Thunberg is often portrayed in the media as someone who sacrifices considerable time and energy $[2,14,15]$. This image is not just a media creation; even Thunberg, in her own speeches, stresses the sacrifices she has had to make. For example, at the 2019 UN Climate Action Summit, Thunberg said, "Yet you all come to me for hope? How dare you! You have stolen my dreams and my childhood with your empty words" [17]. These are powerful claims of sacrifice, and her passionate rhetoric has attracted considerable attention in the media and among her followers [45]. According to TL, idealized attributes suggest that sacrificing one's own comfort and time builds trust and acceptance among followers [34]. Some have recognized Thunberg's sacrifices by addressing how utterly devoted she is to her mission, as articulated in a Facebook group post: "Greta has sacrificed her youth and time for us. Think of all the hours and energy she has spent to protect the future for all of us" [14]. Thunberg not only sacrifices her time and energy, but she puts aside material comforts as well, which strengthens her stance as a figure of moral authority [33].

Second, there is the element of self-sacrifice, in which no personal gain is involved. According to Hanbing and Maolin [38], self-sacrificing leadership is an essential attribute of moral authority. Many claim that Thunberg realizes that her campaign is not about herself and that she appears not to be self-seeking or compromising, being careful to show that she is not making money from all the attention [16,18,46-48]. Bluntly, Thunberg has declared several times that she is not interested in fame or in being a celebrity [47]. For example, Thunberg is irritated that "instead of focusing on the climate and listening to the scientific message, people are instead listening to and talking about me and talking about wanting to take pictures with $\mathrm{me}^{\prime \prime}$ [49]. Saleemul Huq, director of the International Center for Climate Change and Development in Bangladesh, stated: "Speaking as a climatechange scientist who has been working on this issue for 20 years and saying the same thing for 20 years, she is getting people to listen, which we have failed to do" [49]. From a TL perspective, self-sacrificing leadership involves the willingness of a leader to give up personal comfort [50]. McCarthy [22] argues that Thunberg has sacrificed her own 
education, referring to Thunberg's speech delivered to the UN Action Summit in New York, in which she said, "This is all wrong. I shouldn't be standing here. I should be back in school on the other side of the ocean".

Finally, there is the idea of "leading by example," which is an essential attribute of moral authorities, meaning that leaders must sacrifice far more than what they expect of their followers [31]. In one of Thunberg's speeches, she said, "I refuse to be part of the problem. I am not going to contribute to stealing the future of coming generations" [17]. According to Wilk and Cliggett [7], acting to counter climate change is directly related to sacrificing comforts and "needs" in one's daily life. They argue that people are unwilling to change their environmentally damaging behaviors if they are only ordered to do so or educated as to the consequences if they do not [7]. Some argue that Thunberg, by denying herself new clothes, various foods, and comfortable traveling arrangements, evokes people's will to change [51]. Many therefore suggest that Thunberg's sacrifices and conscientious choices constitute powerful and effective arguments in themselves [50,52-56]. Milman [45] demonstrates this by citing a Facebook post: "Thunberg shows us how to respect and protect our environment, by living by example. She is an inspiration." Other findings indicate that many agree, claiming that her sacrifices are what impress people $[12,13,23,57]$. For instance, Thunberg spent 15 days on a zero-emission sailboat to cross the Atlantic Ocean, with no access to showers or other comforts, to take part in climate talks in New York [58]. According to Covey [31], material sacrifices are important, but sacrifices that directly increase the shared vision are more effective in building moral authority. Some argue that the signs of a leader who possesses idealized influence are personal sacrifices that are directly connected to the greater good [2]. According to TL, leaders who become role models will motivate their followers to engage in change and make sacrifices [59]. An interesting observation is that Thunberg does not particularly agree that she makes sacrifices in that sense. She states: "I don't need new clothes. I know people who have clothes, so I would ask them if I could borrow them or if they have something, they don't need any more. I don't need to fly to Thailand to be happy. I don't need to buy clothes I don't need, so I don't see it as a sacrifice" [18].

Peet et al. [6] address resistance to change through the framework of political ecology, stating that most political climate-mitigation efforts are information-based interventions, with threats of what will happen if people do not change. This suggests that there is a belief that people are unaware of the consequences of lifestyle choices for the natural environment and that by giving them the relevant information, they will change their behavior. Furthermore, this suggests that threats and fear motivate people to sacrifice things willingly. According to Peet et al. [6], this is a very ineffective approach. Instead, they promote behavioral interventions that work [6]. Yet, it seems that Thunberg uses information as her basic strategy in calling for change [52-56]. Many claim that Thunberg often refers to science and facts to scare people into understanding that they need to change their behavior $[47,57,60,61]$. However, Raiser et al. [3] claim that it is not the mere scientific facts that attract people's attention, but that they are willing to change their behavior and listen to Thunberg because she confronts them with compelling arguments [3]. Sabherwal et al. [32] refer to such behavior as social comparison, suggesting that this is why Thunberg has had a strong impact on people worldwide. In this context, social comparison refers to people changing their behavior if they notice that they are doing less for the environment than their friends or neighbors are [32]. For instance, previous findings indicate that Thumberg's sacrifices in terms of donating almost all her money to environmental groups have generated social comparison and, thus, change [23,50,62-64]. It is also possible to suggest that Thunberg has endorsed the idea of social comparison by stating: "[I] feel like the youth must sacrifice their own education in order to protest against the destruction of their future," which is suggested to have evoked considerable change [17,26,65-67]. Ferrari [29] states that it is crucial that a transformational leader should understand the effectiveness of social comparison in creating inspirational motivation. 


\subsection{Trust}

According to Covey [31], a moral authority needs to be trustworthy. Trust is defined by Blackford [42] (p. 72) as a "stable belief in the consistency, truth, or ability of someone". Adams [68] states that trust in a leader emerges when the leader's actions are consistent with their pre-existing behaviors and experiences. Some suggest that Thunberg's followers see her as someone they can trust $[25,67,69,70]$, while others question Thunberg's ability to generate trust [21,51,71]. For instance, according to Wu et al. [72], it is absurd to think that Thunberg generates trust among people because she is challenging their ways and even their comfortable existence. According to Landy [21], people do not trust someone who is criticizing them and advocating change. Covey [31] agrees that change often evokes fear and mistrust among people. It is obvious that Thunberg is demanding that people change their behavior and ways of thinking [73-75]. The question, therefore, arises as to how Thunberg can gain people's trust, despite her foremost message being that change is an absolute necessity. An answer may come from the TL framework, which describes, in the intellectual stimulation sub-category, the importance of a leader seeking solutions to a problem from different perspectives [8]. The findings suggest that some believe that Thunberg encourages non-traditional thinking and re-examines critical assumptions as to what is required to ameliorate climate change $[11,15,17]$. These characteristics seem to allow Thunberg to produce results $[26,56,65,76,77]$. For instance, Boucher [78] refers to a Facebook post in which a young person acknowledges their trust in Thunberg by stating: "I love Thunberg... She is telling the truth and we have someone to trust" and "I follow Thunberg [be]cause she is telling the truth". Additionally, Thunberg herself is asking people to trust her, through statements such as: "2020 was the hottest year ever recorded according to NASA. The last 6 years have been the hottest 6 years on record. We are in a climate emergency and the changes needed to avoid the worst consequences are still nowhere in sight. The only one who can change that is you and I. Spread awareness. Be the change" [17].

Some authors argue that trusting someone is a slippery slope for the younger generation $[3,72,79]$. Through social media and electronic news, nearly everyone has access to world events. However, the media are not portraying just one truth [3,72]; rather, contradictory theories and biased news reports are available [65,72]. This makes one wonder how to determine what and whom to trust, just as the younger generation is confronted with multiple truth and reality claims. Some media blame one another for being biased and spreading "fake news," arguing that they consider themselves as the only ones to provide "real" facts [2]. Dalal [80] draws attention to this matter, arguing that social media and online media sources allow more people to be heard. There is ongoing debate as to whether access to news reports creates a more nuanced understanding among news recipients, or whether individuals simply become more selective about what they read, only taking notice of the news/facts that reaffirm their preconceptions [58,80]. Regardless, there is a strong belief that the current media situation has led to an increase in the mistrust of science $[2,5,80]$. Experiencing climate change and acknowledging the consequences of human impacts on the natural environment require that young people trust scientific experts [5]. Despite the general mistrust of science, Thunberg is urging people to listen to the experts $[19,46,49,74]$. The foremost statement of the leading climate change youth movement, Fridays for Future, is that officials and other public actors ought to "listen to the science," meaning that trusting science is the essence of this youth engagement [51]. It is unclear why Thunberg's call to trust science is so well-received, while many others have failed in making the same call $[20,45]$. Some suggest that her emphasis on science has not contributed to Thunberg's ability to evoke trust and be a moral authority $[21,24]$. Rather, due to Thunberg's other characteristics, her followers trust the science of climate change that she presents $[21,23,24]$. To conclude, in this era of constant access to news, different "realities," and contradictory "truths," Thunberg has become someone people rely on and trust. 
Roberts and Parks [79] discuss how mistrust concerning climate change, environmental justice, and the need for sustainable living is fueled by the media, through its presentation of contradictory facts. They also suggest that guilt might be important in fostering mistrust since acknowledging climate change involves accepting one's own role in perpetuating the problem [79]. Within this context, many are puzzled as to why Thunberg evokes trust among so many $[47,50,52,57,62,81]$. The confusion emerges because, on countless occasions, Thunberg has painted very bleak images of our future, or lack thereof, if people do not change their habits $[23,48,57]$. However, some authors argue that, despite the guilt that climate change generates among people, Thunberg is trusted because she offers something that political leaders do not $[5,58,80]$ : she apportions blame to political leaders [2]. Lynch [82] states that it is easier to act against something when someone else is responsible for it. Those who initially failed to accept the reality of climate change (out of guilt), can now become engaged in climate change activism. The findings of the literature review indicate that Thunberg provides a context in which people can avoid feeling guilty for their lifestyle and the fear that the solutions and responsibility lie with them $[69,83]$. Thunberg directs attention to the political leaders themselves, allying with the masses as victims of the poor decisions made by those in power [54,63]. The findings suggest that Thunberg offers solutions in which political leaders and other global forces are to blame and are mainly responsible for acting differently $[25,67,69,70]$.

\subsection{Courage}

Courage is a universal trait among moral authorities [8,29-31]. According to Dongwon et al. [84], leaders display courage when they challenge the authorities and established power centers. Covey [31] describes courage as a vital element in gaining moral authority. Thunberg has displayed considerable courage in challenging powerful leaders, even when they verbally attack her $[3,24,32,39,55]$, for instance, when the Russian president, Vladimir Putin described Thunberg as "a kind and very sincere girl, who doesn't understand the complexities of the modern world" [83]. Brazil's far-right president Bolsonaro labeled her a "brat" (Hesse, 2019). On 23 September 2019, Michael Knowles of Fox News referred to Thunberg as a "mentally ill Swedish girl" when dismissing any reason to follow her lead [65]. Some argue that Thunberg gains followers through her fearless approach to those who criticize and mock her $[17,25,85]$. Many experienced leaders find it challenging to handle personal attacks without descending to the same level by making counterattacks $[10,29]$. Thunberg, however, seems to handle such attacks by sticking to her convictions $[13,22,67]$.

Several articles have struggled to understand how Thunberg- a young girl from Sweden - has managed to find not only the motivation to continue her quest, but also the courage to respond to those who patronize and belittle her $[16,54,60,61,66]$. Some believe that her steadfastness is what makes her a moral authority [2,12,52,62]. Many suggest that her Asperger's diagnosis allows her to stay focused, hindering her from becoming emotional in response to the criticism she faces $[3,32,55]$. For instance, Thunberg's speech at the 2019 UN Climate Action Summit in New York demonstrated her courage in addressing world political leaders $[53,58,63,69]$. She stated: "We are in the beginning of a mass extinction and all you can talk about is money and fairy tales of eternal economic growthhow dare you!" [12]. A prominent attribute of Thunberg is her fearlessness and courage as she advances in the face of criticism. Every leader needs courage to make hard decisions, implement changes, and articulate a vision [10]. In this context, Thunberg is able to courageously stand up to the established system and question global politicians.

Many authors believe that Thunberg's courage is displayed in her anger [2,12,52,62]. Adams [68] states that several great leaders have utilized anger to gain followers. TL sees anger as a beneficial attribute but emphasizes "focused anger," which can display courage, evoke change, and thus encourage followers [9]. On the other hand, according to Covey [31], successful leaders should hide their true emotions and especially avoid expressing anger. Martin Luther King Jr. once clarified: "You could be angry that the system is oppressing you, but try not to direct that anger toward people who were caught up in 
that system, but channel it to the system itself. Use the anger to act without violence" [68]. Dongwon et al. [84] seem to agree with Martin Luther King Jr., arguing that anger should target action rather than people. Conversely, the findings show that Thunberg directs her anger mainly toward people and only occasionally toward actions $[14,17,25,26,64]$. This can be illustrated by her response to one journalist's question: "If everyone is guilty, then no one is to blame, and someone is to blame ... Some people, some companies, some decision-makers, in particular, know exactly what priceless values they have been sacrificing to continue making unimaginable amounts of money, and I think many of you here today belong to that group of people" [21]. Thunberg's focused anger has been discussed in both positive and negative terms in the media $[22,58]$. Some disparage Thunberg's anger [54,63,69]. Sridham [61], for example, claims that Thunberg has not earned the right to be angry. He argues that Thunberg-and her generation-should be thankful for the privilege of being able to care about the environment [61]. He continues, stating that Thunberg's anger and allegations are counter-productive by dividing people into different camps, for which they are definitely not responsible [61]. However, some consider criticism like Sridham's of Thunberg as coming from a gender perspective [49,51]. Regarding the criticism of Thunberg, they suggest that much of the disparagement relates to Thunberg's being female and that women's expression of anger is never well-received [16,18,24]. Anger from female leaders has been suggested to lack efficacy compared with anger from male leaders $[29,59,68,83]$. Dongwon et al. [84] studied leadership, courage, and anger. They found that when men in leadership positions displayed focused anger regarding a shared cause, people responded with commitment and trust. When women, on the other hand, showed focused anger, they were accused of being overemotional, untrustworthy, and insecure [84]. Overall, however, Thunberg's anger has evoked a positive response among her followers and could well be a source of her moral authority $[48,54,55,63,75,77]$. The UN Secretary-General, António Guterres stated: “My generation has failed to respond properly to the dramatic challenge of climate change. This is deeply felt by young people. No wonder they are angry" [15].

\subsection{Hope}

According to Goethals and Sorenson [33], few studies have examined the relationship between TL and hope. On the other hand, the concept of hope is often addressed in traditional leadership theories, such as traits theory [9]. Interestingly, this study found that the term "hope" is used in TL without specifying it as a necessary quality $[2,9,27,32,33,86]$. For instance, leaders with attributes such as idealized influence and inspirational motivation evoke hope among their followers to achieve desirable goals through communication, being role models, and establishing patterns for identification $[2,9,27,32,33,86]$. The findings indicate that Thunberg generates hope in two ways, firstly by her celebrity status and secondly, by decreasing eco-anxiety among the younger generation $[53,66,70,78,81]$.

Thunberg has managed to attract global attention by offering hope $[16,45,49,58]$. Blackford [30] argues that her accomplishments in terms of gaining fame and recognition as a moral authority are reasons in themselves for hope among young people. In other words, fame on its own can generate hope. Some believe that because Thunberg has gained celebrity status, younger people look up to her and feel hope that their voices can also be heard [5,65,76]. Williams [47] suggests that the media attention given to Thunberg has led to a feedback loop. Blitzer [65] says that "young people are getting so much attention that it draws more young people into the movement." Due to modern communication technology, many young people can strive for fame and create a platform from which to spread their messages $[5,68,80]$. Lord [23] agrees, and refers to a Facebook post, stating: "Finally, we have a voice. We are the next generation that will inherit this world. We should be able to have a voice. I feel so much hope", and "Thanks, Thunberg, you have forced the world to listen to us." However, some question Thunberg's fame and the attention she receives, stating that she is not the first young climate activist with charismatic attributes, nor the first with a clear message [32,62,69]. According to Dana 
Fisher, a sociologist who studies activism, young people have discussed climate change for quite some time [20]. Therefore, many are puzzled as to why Thunberg has attracted so much attention $[5,68,80]$. Some believe that Thunberg's moral authority has emerged through her unconventional approach $[3,50,57,72]$. That is, rather than conveying the message that, for example, the polar bears and the rainforest need protection, Thunberg focuses on the human-environment connection, stressing global justice [12,22,23,70]. This was acknowledged by Harriet Thendra, an environmental social scientist, who stated: “Thunberg's message isn't about saving the rainforest or saving whales; it is about saving the most vulnerable people on Earth" [57].

Studies have supported the existence of "solastalgia" among the younger generation [32]. In other words, there is increased hopelessness and anxiety among young people worldwide, also referred to as eco-anxiety [72]. Many argue that Thunberg has provided a sense of hope that humankind can overcome global warming and find patterns of sustainable living [11,20,25,46]. According to the Public Health Agency of Sweden [87], every fifth Swedish 12-year-old states that they are "very often or often" worried about climate change. Thunberg can therefore be seen as a source of hope among the younger generation. For example, she has said: "As long as you are doing everything you can now, you can't let yourself become depressed or anxious" and "there are signs of change, of awakening" [63]. However, some suggest that Thunberg's being a source of hope is ironic $[49,69,71]$. In various public speeches, her rhetoric has been frightening and negative, as in: "Why should we study for a future that may not exist anymore?" [16]. Thunberg depicts a rather frightening future for humankind, with melting ice caps and glaciers, rising ocean levels, and increasingly extreme weather events [14,18,24,61,64]. Lord [23] illustrates this by referring to a Facebook post: "Thunberg is the reason children and teenagers fear their future and feel anxiety. She is to blame for stealing the childhood from so many". Yet Röstlund [60] does not blame Thunberg, stating that children and young people were suffering from eco-anxiety long before Thunberg gained fame. Thunberg has repeatedly claimed that her message is derived from hope, not from despair. She says, for example: "The school-striking children, when I see them-that is very hopeful. And also, the fact that people are very unaware of the climate crisis. I mean, people aren't continuing like this and not doing anything because they are evil, or because they don't want to. We aren't destroying the biosphere because we are selfish. We are doing it simply because we are unaware. I think that is very hopeful, because once we know, once we realize, then we change, then we act" [57].

\subsection{Belonging}

According to TL, a leader both requires interpersonal capacities and should be a model for identification and imitation, as identified by Northouse [34]. Furthermore, Mayberry [28] states that a moral authority must create a sense of belonging and be accessible to others. This can be challenging for environmental leaders, as they need to influence people from different cultural settings [6]. Mayberry and Northouse [28,34] continue to argue that environmental leaders need to evoke willingness among their followers to change set behaviors and live in greater harmony with the natural environment [6]. Plumwood [88] acknowledges the complexity of this expectation by stating that environmental behaviors directly relate to their cultural setting. This implies that for individuals to change their relationship with the natural environment, their cultural morality and norms need to change. Wilk and Cliggett [7] add to this complexity, arguing that an individual's moral principles are fixed and are taught in childhood, whereas moral values differ greatly, depending on the cultural setting. Some anthropologists clarify that every culture is convinced that its moral principles are coherent with the natural order [88].

In this context, morality is bound to a specific culture and can only stay within the boundaries allowed by that culture. Plumwood [88] even goes so far as to claim that acting to counter climate change, or even accepting its existence, is thoroughly dependent on the cultural setting. However, the present findings suggest the contrary. Many 
believe that Thunberg has to some degree overcome cultural as well as economic differences $[2,17,50,52,62]$. One possible explanation for this accomplishment is that those who follow Thunberg are somewhat disconnected from their cultural norms and morals. This would be in accordance with Wilk and Cliggett's [7] argument that some people are more influenced by their culture than others. Prior to Thunberg's appearance, many young people from different cultural backgrounds were already creating sub-cultures to fight climate change $[3,15,60,63,70]$. According to Thomas et al. [51], young people worldwide had already mobilized mass climate protests and demonstrations, before Thunberg became well-known. Curnow [26] states that many activists from indigenous groups had previously acted and fought for environmental justice, displaying more charisma, leadership personality, and skills than Thunberg has. However, Caldwell [85] argues that they did not get the same recognition because many of these young activists were people of color. Curnow [26] claims that Thunberg's moral authority has a lot to do with race: her whiteness and her status as a "privileged" girl are crucial in explaining why governments, the media, and the UN acknowledge her to the extent that they do [26]. The racial aspect of Thunberg's fame has been discussed in several contexts $[23,56,57,73,76]$. For instance, Hesse [17] discusses Thunberg and race, referring to the Facebook post of a young girl: "I hope [just as] much attention will be given to a number of kids of color who have been at the frontline of activism to act against climate change for decades".

Whether or not Thunberg has become an environmental leader due to her race, the world needed a global leader who could cross political, cultural, and religious boundaries [89]. According to Blitzer [65], the younger generation, in particular, was craving someone to unite them in their fear of the changing natural threats around them. Blitzer [65] supports his claim by referring to the Facebook post of a young girl from Nigeria: "Internally displaced peoples, farmer-herdsmen clashes, insecurity-all driven by climate change. Also, the increase in food prices, floods sweeping away farmers' land, droughts affecting the yield of crops, and excessive rainfall. We need someone to lead us against the greatest war ever known by humankind. The war to protect our climate" [65]. Being a transformational leader requires the ability to foster a sense of collective identity [34]. According to Fielding and Hornsey [89], collective identity emphasizes the need felt by people to belong to a group and for the individuals in that group to alter their individual identities in favor of a collective identity. Some believe that Thunberg has accomplished this through mobilizing people and collectively addressing global warming $[8,32,55,66,67,77]$ in what some refer to as the "Greta Thunberg effect" [11,26,46,50]. Fielding and Hornsey [89] argue that the cultural norms surrounding individuals are what ultimately determine how people position themselves regarding climate change. Furthermore, they suggest that collective identity may even override cultural norms [89]. This means that while cultural norms are of great importance, collective identity is a stronger influence upon inducing individuals to change their behavior. Stanley [27] emphasizes the need for leaders to create a collective identity among their followers to facilitate transformational processes. Fielding and Hornsey [89] state that if people can embrace a social identity in relation to acting against climate change, then they will become involved in pro-environmental behavior. Thunberg, thus, offers the younger generation a truth that goes beyond political, class, and religious differences, which is an essential characteristic within the individual consideration subcategory in TL [34].

Thunberg is both a child and a girl, two qualities that evoke either acceptance or rejection of her message. Some suggest that Thunberg depicts the climate as a generational issue, with adults having stolen their children's future, instead of primarily being a class issue $[21,45,66,67,75]$. Grossman [66] discusses this, citing a Facebook post reading: “The older generation messed things up and we are doing the cleanup". However, according to Roberts and Parks [79], there is a clear division between the political right and left when discussing climate change. The present findings clearly suggest that the "Greta Thunberg effect" is more appealing to some than to others $[13,17,55,77]$. Thunberg's followers tend to espouse a more liberal rather than a conservative political ideology $[32,64,66,71]$. Sabher- 
wal et al. [32] note that those who see Thunberg as familiar and resembling them are more likely to follow her. Payne [77] argues that attributes such as being of a similar age group, political ideology, socioeconomic living situation, and cultural setting play an essential role in the willingness to recognize Thunberg as a leader. Most of Thunberg's followers seem to be roughly $15-25$ years old $[15,22,48,50,54,75]$. Another important factor is that Thunberg has often referred to herself as a child $[67,69,78,85]$, for example, when Thunberg said: "Adults keep saying, 'We owe it to young people to give them hope.' But I don't want your hope. I don't want you to be hopeful. I want you to panic. I want you to feel the fear I feel every day, and then I want you to act. I want you to act as you would in a crisis. I want you to act as if our house is on fire. Because it is" [16]. By doing so, she aligns herself with young people, making them feel that she is one of them $[26,58,69]$. As Chomsky and Pollin [58] have commented, "she is providing an arena where the younger generation can find a social identity".

Thunberg's young age has been highlighted by the media, by Thunberg herself, and by her followers. Although Thunberg's young age could be a source of her moral authority, it is also possible to find disadvantages in it $[11,47,58,70]$. For instance, those who are critical of Thunberg often refer to her as a "child" to belittle her mission and appearance $[12,49,65,74,85]$. Some argue that this infantilization is similar to stereotypical accusations used to silence women, such as hysteria, emotionality, mental instability, and inability to think for themselves $[15,77,78]$. The gender aspect should not be ignored as it has far-reaching historical roots. According to Vertigan and Nelson [83] and Plumwood [88], climate denialism is connected with the masculine identity, with the idea of the conquest of nature being intertwined with that of industrial capitalism. They argue that industrial capitalism is made by and for men, and that the core essence of being a "man" is questioned when one criticizes industrial capitalism $[83,88]$. Nonetheless, despite her age and gender having been used against her, Thunberg herself has repeatedly referred to her young age as being useful in advancing her mission, which many have seen as successful $[15,22,48,50,54,75]$.

\section{Summary of Main Findings}

Table 2 summarizes the findings connected to the five characteristics of moral authority.

Table 2. Characteristics of Thunberg's moral authority.

\begin{tabular}{|c|c|c|c|c|}
\hline Sacrifice & Trust & Courage & Hope & Belonging \\
\hline $\begin{array}{c}\text { Sacrifices time, energy, } \\
\text { and material comforts } \\
{[3,13,18,25,26,28,34,47,48,} \\
53,54]\end{array}$ & $\begin{array}{c}\text { Engenders trust } \\
\text { among her followers } \\
{[3,5-7,11,15,23,24,29,} \\
36,44,47,48,51]\end{array}$ & $\begin{array}{c}\text { Displays courage when } \\
\text { standing up to and } \\
\text { challenging powerful } \\
\text { leaders } \\
{[1,8,12,27,35,38,46,48]}\end{array}$ & $\begin{array}{l}\text { Celebrity status makes } \\
\text { younger people look up } \\
\text { to her and feel hope that } \\
\text { their voices can also be } \\
\text { heard }[4,16,34,45,53]\end{array}$ & $\begin{array}{c}\text { Overcomes cultural } \\
\text { and political } \\
\text { indifference and } \\
\text { establishes a new } \\
\text { sense of belonging } \\
{[5,6,11,22,36,47]}\end{array}$ \\
\hline $\begin{array}{c}\text { Sacrifices have an } \\
\text { immediately positive } \\
\text { effect on the natural } \\
\text { environment }[2,4,9,13,16 \text {, } \\
\quad 17,27,42,49,55]\end{array}$ & $\begin{array}{l}\text { People tend to trust } \\
\text { her because she } \\
\text { urges people to trust } \\
\text { science and not her } \\
{[3,5,7,11,23,24,48,51]}\end{array}$ & $\begin{array}{l}\text { Displays "focused } \\
\text { anger" toward the } \\
\text { established system as } \\
\text { well as specific } \\
\text { individuals } \\
{[6,12,36,38,49]}\end{array}$ & $\begin{array}{c}\text { Some believe that she } \\
\text { gives hope to a } \\
\text { generation experiencing } \\
\text { eco-anxiety } \\
{[7,15,22,33,54]}\end{array}$ & $\begin{array}{c}\text { The younger } \\
\text { generation needs a } \\
\text { leader who unites } \\
\text { them in their } \\
\text { eco-anxiety } \\
{[5,6,11,22,34]}\end{array}$ \\
\hline $\begin{array}{c}\text { Self-sacrifice and no } \\
\text { interest in gaining } \\
\text { benefits } \\
{[6,7,11,19,38,39,51]}\end{array}$ & $\begin{array}{l}\text { Provides a context in } \\
\text { which people can } \\
\text { avoid feeling guilty } \\
\text { about how they live } \\
\text { because the } \\
\text { responsibility } \\
\text { belongs to political } \\
\text { leaders } \\
{[1,14,18,27,31,52,53]}\end{array}$ & & $\begin{array}{l}\text { Some believe that she is } \\
\text { the cause of eco-anxiety } \\
\qquad[9,13,37,42]\end{array}$ & $\begin{array}{l}\text { Provides a collective } \\
\text { identity }[10,16,41]\end{array}$ \\
\hline
\end{tabular}


Table 2. Cont.

\begin{tabular}{|c|c|c|c|c|}
\hline Sacrifice & Trust & Courage & Hope & Belonging \\
\hline $\begin{array}{l}\text { Leads by example-as a } \\
\text { role model she sacrifices } \\
\text { her own needs and } \\
\text { comforts to encourage } \\
\text { others to sacrifice } \\
{[3,11,24,28,30,43,44,50]}\end{array}$ & $\begin{array}{c}\text { Flexible enough to } \\
\text { change while } \\
\text { showing consistency } \\
\text { over time } \\
{[2,9,10,17,21,25,32} \\
37-39,43,45,50]\end{array}$ & & & $\begin{array}{c}\text { Uses her age to evoke } \\
\text { a sense of unity } \\
\text { among her followers } \\
{[3,7,8,13-15,20,25,29,} \\
33,46,53,54]\end{array}$ \\
\hline
\end{tabular}

Balances

information-based and

behavioral interventions

$[2,7,15,25,27,47,52,53]$

Sacrifices to evoke social

comparison $[18,21,47,52]$

Table 3 summarizes the findings connected to the four elements in TL.

Table 3. Qualities of Thunberg as a transformational leader.

\begin{tabular}{|c|c|c|c|}
\hline Inspirational Motivation & Idealized Influence & $\begin{array}{l}\text { Individualized } \\
\text { Consideration }\end{array}$ & Intellectual Stimulation \\
\hline $\begin{array}{l}\text { Sacrifices benefits and needs, } \\
\text { evoking social comparison among } \\
\text { people }[3,18,21,26,28,34,47,52-54]\end{array}$ & $\begin{array}{c}\text { Engages with her followers } \\
\text { and sacrifices her own needs } \\
\text { to commit to the shared goal } \\
{[4,9,13,16,17,27,42,49,55]}\end{array}$ & $\begin{array}{c}\text { Provides a collective } \\
\text { identity via the "Greta } \\
\text { Thunberg Effect" } \\
{[7,8,10,16,20,41,54]}\end{array}$ & $\begin{array}{c}\text { Encourages non-traditional } \\
\text { thinking and challenges existing } \\
\text { truths }[3,11,23,24,36,51]\end{array}$ \\
\hline $\begin{array}{c}\text { Offers solution to climate change } \\
{[3,5,7,11,23,24,27,31,48,51,52]}\end{array}$ & $\begin{array}{c}\text { "Leads by example" by } \\
\text { sacrificing benefits and } \\
\text { comforts } \\
{[3,11,24,28,30,43,44,50]}\end{array}$ & $\begin{array}{l}\text { Offers the young } \\
\text { generation a truth that } \\
\text { goes beyond political, } \\
\text { class, and religious } \\
\text { differences } \\
{[5,6,11,22,36,47]}\end{array}$ & $\begin{array}{c}\text { Relies on facts and science to } \\
\text { strengthen her mission } \\
{[1,5,7,11,23,24,48,51]}\end{array}$ \\
\hline $\begin{array}{c}\text { "Focused anger"—-displays } \\
\text { courage, invokes change, and } \\
\text { encounters followers } \\
{[1,6,8,12,27,35,36,38,46,49]}\end{array}$ & $\begin{array}{c}\text { Becomes a role model through } \\
\text { self-sacrifice } \\
{[6,7,11,19,38,39,51]}\end{array}$ & $\begin{array}{c}\text { Provides a sense of } \\
\text { belonging, enabling a } \\
\text { collective and social } \\
\text { identity }[3,7,8,10,14- \\
16,20,25,29,41,46,54]\end{array}$ & $\begin{array}{c}\text { Encourages new ideas and } \\
\text { engages in a problem-solving } \\
\text { approach }[2,7,15,25,27,47,52,53]\end{array}$ \\
\hline $\begin{array}{l}\text { Provides a sense of meaning and } \\
\text { challenges global leaders } \\
{[6,11,12,14,18,22,27,33,34,38,53]}\end{array}$ & $\begin{array}{c}\text { Embodies the qualities that } \\
\text { she wants among her } \\
\text { followers } \\
{[3,10,11,16,18,28,30,43,50,54]}\end{array}$ & $\begin{array}{c}\text { Empowers her followers } \\
\text { to counter climate } \\
\text { change }[4,15,16,22,33,34, \\
45,53,54]\end{array}$ & $\begin{array}{l}\text { Re-examines critical } \\
\text { assumptions as to what is } \\
\text { required to reduce climate } \\
\text { change }[3,16,23,36,43,51]\end{array}$ \\
\hline $\begin{array}{c}\text { Promotes a consistent vision, } \\
\text { mission, and set of values } \\
{[3,6,7,11,15,23,36,44,51]}\end{array}$ & $\begin{array}{l}\text { Upholds high ethical } \\
\text { standards } \\
{[3,11,24,28,30,43,44,50]}\end{array}$ & $\begin{array}{l}\text { Establishes a clear } \\
\text { concept of what is } \\
\text { "right" and "wrong" } \\
{[3,11,16,28,30,43,44,51]}\end{array}$ & $\begin{array}{l}\text { Provides solutions } \\
{[3,6,15,29,44,47,51]}\end{array}$ \\
\hline
\end{tabular}

\section{Discussion}

TL theory is recognized as being the most prominent leadership theory [9]. TL argues that leaders should motivate and inspire their followers to accomplish their common goals. Despite the advantages of TL, as discussed here, it is important to address the attributes of transformational leadership and moral authority from a critical perspective [9].

Leaders with transformational attributes are great visionaries and motivators [29]. This kind of leader can convince individuals and groups to believe in and trust them. It is, therefore, essential that such leaders have a high moral code and should not be self-serving [33]. There is the risk that a leader with such skills could use them for less-thanhonorable purposes, convincing their followers to act in a questionable manner. However, 
this study provides data showing that Thunberg's intentions are consistent and nothing short of honorable, both of which are key attributes of a moral authority. Still, it is vital to acknowledge the power that Thunberg possesses and continue to evaluate her morals and intentions. In addition, according to Isserow and Klein [59], a moral authority serves as a parallel actor to traditional political authorities. They argue that both politicians and moral authorities create laws/rules that determine whether rules or laws have been broken and then enable the meting out of punishment [59]. This means that being a moral authority could bring power equal to that of a political leader. Thunberg, in some respects, possesses the same power over people as do other more traditional, established world leaders. If we also assume that Thunberg has become an authority with transformational leadership skills, then she has obtained varied control and influence over her followers. However, it is crucial to keep in mind that political leaders are the ones who will ultimately have to formulate legislation and rules addressing climate change. Therefore, although Thunberg criticizes political leaders and accuses them of inaction, her ultimate goal is to influence and/or pressure them to act against climate change. It is therefore a slippery slope to make political leaders the enemy, as they will be the ones to make the decision to adopt green governance.

\section{Future Research Directions}

This article identifies the leadership characteristics of Thunberg as a moral authority within the framework of TL. Three areas are discussed as potential targets for future research, based on the framework in Figure 1 (page 2). Firstly, within the framework of moral authority, this article identifies five typical characteristics: sacrifice, hope, trust, courage, and belonging. Through future research, it would be valuable to study how this framework of moral authority relates to other forms of leadership, such as the model of credible leadership [9]. For example, the findings in this study suggest that Thunberg's age, race, and gender contribute to her becoming a transformational leader. Would these attributes play an equal role if a study was based on Kouzes and Posner's leadership credibility theoretical framework [9]? Secondly, future research may include quantitative research with a factorial design, enabling the possibility of looking at the five characteristics of a moral authority as independent variables. The purpose here would be to examine which variable/factor has the most effect and the interaction between the different variables. The results would show, for instance, if the five characteristics of a moral authority are dependent upon each other, which characteristic is dominant, and whether any of the characteristics lacks value to be a moral authority. Finally, it would be interesting to research whether Figure 1 (page 2), the framework of moral authority and TL, applies in other cases of leaders and activists on climate change and sustainability. In other words, to see the prospect for generalizability of the discussions based on findings from this systematic literature review.

\section{Limitations}

Using popular journalistic articles and academic publications does not always provide the most up-to-date statistics and knowledge. In this sense, the data gathered here might not be relevant in the future (or even today, as this article is being read). Another limitation is that systematic reviews base their arguments on data previously collected by others, so the success of this study relies on the quality of previous research. Still, a pragmatic approach takes account of the various limitations of a method, and drawing conclusions based on the review of multiple studies is believed to improve our understanding of a given research problem [43].

One challenge with a rather fixed theory such as TL is that one may become biased, analyzing the findings only as they fit the framework. Utilizing an abstract theory, such as $\mathrm{TL}$, in such a context calls for an in-depth understanding of the theory. In this study, there was a preconception that Thunberg was considered a moral authority. If we accept that Thunberg is such an authority, then it is vital to acknowledge that the lens through which 
the findings were analyzed was colored by that preconception. Robson [43] highlights the importance of being aware of relevant preconceptions in order to understand a researcher's position and attitudes toward the content that is gathered. The ATLAS.ti, Scientific Software Development $\mathrm{GmbH}$, Berlin, Germany enhanced our ability to distinguish the researchers' perspective from the empirical data. Bengtsson [39] refers to this as "bracketing," stating that it is a vital process in qualitative research. Finally, it is important to consider cultural and other biases. Whether we are aware of them or not, we all have biases [90]. Thunberg is Swedish, as are the present researchers. This resemblance might have influenced us, making us more sensitive to Thunberg's accomplishments. However, the theoretical framework and the use of a content analysis design increased our ability to objectively gather and analyze the chosen data, while the use of reflexive memos in ATLAS.ti, Scientific Software Development $\mathrm{GmbH}$, Berlin, Germany, helped us to address our subjective biases.

\section{Conclusions}

This article argues that Thunberg embodies five main characteristics-sacrifice, trust, courage, hope, and belonging - that have made her a moral authority in the fight against climate change. Through this position, she has developed certain personality attributes and a relationship with her followers that are aligned with the four subcategories of transformational leadership: inspirational leadership, idealized influence, individualized consideration, and intellectual stimulation. Thunberg is today seen as a leading figure whose voice is heard globally by leaders and politicians. She offers a new approach to environmental leadership. As a moral authority, Thunberg has established herself as a transformational leader who unites people, regardless of their country, culture, economic status, religion, or political beliefs. Climate change is one of the greatest challenges of our time. Thunberg is perhaps part of the solution that we need.

Author Contributions: Conceptualization, N.N. and K.R.; methodology, N.N. and K.R.; software, N.N. and K.R.; validation, N.N. and K.R.; formal analysis, N.N.; investigation, N.N.; resources, N.N.; data curation, N.N.; writing-original draft preparation, N.N.; writing—review and editing, K.R.; visualization, K.R.; supervision, K.R.; and project administration, K.R. All authors have read and agreed to the published version of the manuscript.

Funding: This research received no external funding.

Data Availability Statement: Not applicable.

Acknowledgments: This article is based on a Master's thesis. We are therefore grateful for the comments from the Examiner and peer-reviewers from the University of Lund, Sweden.

Conflicts of Interest: The authors declare no conflict of interest.

\section{References}

1. NASA-Earth Science Communications Team at NASA's Jet Propulsion Laboratory. In The Effects of Climate Change; University of California: Merced, CA, USA, 2021.

2. Zulianello, M.; Ceccobelli, D. Don't Call it Climate Populism: On Greta Thunberg's Technocratic Ecocentrism. Polit. Q. 2020, 6, 623-631. [CrossRef]

3. Raiser, K.; Kornek, U.; Flachsland, C.; Lamp, W.F. Is the Paris Agreement effective? Environ. Res. Lett. 2020, 15, 13-45. [CrossRef]

4. Fuhr, L.; Unmusig, B.; Verolme, H. A Future for International Climate Politics—Durban and Beyond; Heinrich-B: Berlin, Germany, 2011.

5. Bryant, R. The International Handbook of Political Ecology; Elger Publishing: London, UK, 2015; ISBN 9780857936172.

6. Peet, R.; Robbins, P.; Watts, M.J. Global Political Ecology; Routledge: London, UK, 2011.

7. Wilk, R.; Cliggett, L. Economies and Culture: Foundations of Economic Anthropology; Westview Press: Cambridge, MA, USA, 2007.

8. Daston, L.; Vidal, F. The Moral Authority of Nature; University of Chicago Press: London, UK, 2013.

9. Clark, T.R. Leading with Character and Competence; Berrett-Koehler Publisher: Oakland, CA, USA, 2016.

10. Evans, L.; Hicks, C.; Cohen, P.; Case, P.; Prideaux, M.; Mills, D. Understanding Leadership in The Environmental Science. Ecol. Soc. 2015, 20, 46. [CrossRef]

11. Beeler, C. How did teen climate activist Greta Thunberg rise to fame so quickly? The Guardian. Available online: https://www. theguardian.com/environment/2019/sep/26/greta-thunberg-teenager-on-a-global-mission-to-make-a-difference (accessed on 3 January 2021). 
12. Björkman, E. Greta Thunberg och Zlatan i topp på Instagram. Svenska Dagbladet. Available online: https://www.svd.se/gretathunberg-och-zlatan-i-topp-pa-instagram (accessed on 8 January 2021).

13. Gibson, C. Before Greta Thunberg was a global icon, she was a tormented child who refused to eat or speak. Washington Post. Available online: https:/ / www.washingtonpost.com/gdpr-consent/before-greta-thunberg-was-a-global-icon-she-wasa-tormented-child-who-refused-to-eat-or-speak_story.html (accessed on 4 January 2021).

14. Marchese, D. Greta Thunberg Hears Your Excuses. She is not impressed. New York Times. Available online: https://www.nytimes. com/interactive/2020/11/02/magazine/greta-thunberg-interview.html (accessed on 15 January 2021).

15. Dixon, E. Greta Thunberg's Perfect Response to Donald Trump Just Won Twitter. New York Times. Available online: https: //www.marieclaire.com/politics/a34596557/greta-thunberg-trump-tweet/ (accessed on 5 January 2021).

16. Rincon, P. Greta Thunberg: People underestimate “angry kids". BBC News. Available online: https://www.bbc.com/news/ science-environment-50644395 (accessed on 8 January 2021).

17. Hesse, M. Greta Thunberg weaponized shame in an era of shamelessness. Washington Post. Available online: https: / / www.washingtonpost.com/gdpr-consent/?next_url=https $\% 3 \mathrm{a} \% 2 \mathrm{f} \% 2 \mathrm{fwww} . w a s h i n g t o n p o s t . c o m \% 2 f l i f e s t y l e \% 2 \mathrm{fstyle} \%$ 2fgreta-thunberg-weaponized-shame-in-an-era-of-shamelessness \%2f2019\%2f09\%2f25\%2f66e3ec78-deea-11e9-8dc8-498eabc1 29a0_story.html (accessed on 3 January 2021).

18. Mishan, L. How Shouting, Finger Waving Girls Became Our Conscience. New York Times. Available online: https:/ /www.nytimes. com/2020/09/30/t-magazine/girls-women-revolution.html (accessed on 8 January 2021).

19. Thunberg, G.; Thunberg, S.; Ernman, M. Our House Is on Fire: Scenes of a Family and a Planet in Crisis; Bokförlaget Polaris: Stockholm, Sweden, 2018.

20. Marris, E. Why young climate activists have captured the world's attention. Nat. Res. J. 2019, 6, 471-476. [CrossRef] [PubMed]

21. Landy, H. Noa 16-year-old tells Davos delegates that if the planet dies, she's blaming them. QUARTZ. Available online: https:/ / qz.com/1533904/greta-thunberg-blames-davos-delegates-for-climate-change/ (accessed on 15 January 2021).

22. McCarthy, T. ‘Currently chilling': Greta Thunberg ridicules Trump's angry tweets. The Guardian. Available online: https:/ /www. theguardian.com/us-news/2019/dec/12/trump-angry-tweets-greta-thunberg-prompt-humorous-response-teen-activist (accessed on 8 January 2021).

23. Lord, M. Listen to Science. Boston Review. Available online: https://bostonreview.net/reading-lists-science-nature/matt-lordboston-review- \%e2\%80\%9clisten-science $\%$ e2\%80\%9d (accessed on 7 January 2021).

24. Phillips, K. The Gospel of Oil. Boston Review. Available online: https://bostonreview.net/philosophy-religion/kim-phillips-feingospel-oil (accessed on 8 January 2021).

25. Ewald, H. Hatkampanj mot Greta Thunberg i Indien. Dagens Nyheter. Available online: https://www.dn.se/varlden/hatkampanjmot-greta-thunberg-i-indien/ (accessed on 8 January 2021).

26. Curnow, J.; Helferty, A. A year of resistance: How youth protests shaped the discussion on climate change. Vancouver Sun. Available online: https:/ / vancouversun.com/opinion/op-ed/joe-curnow-and-anjali-helferty-a-year-of-resistance-how-youthprotests-shaped-the-discussion-on-climate-change (accessed on 3 January 2021).

27. Stanley, A. Next Generation Leaders; Random House Inc.: New York, NY, USA, 2011.

28. Mayberry, T.C. The Monist_-Virtue and Moral Goodness; University Press: Oxford, UK, 1970.

29. Ferrari, L. The Influence of Moral Authority in International Relations: A Case Study of the Catholic Church under John Paul II; Georgetown Univrsity: Washington, DC, USA, 1998.

30. Blackford, R. The Mystery of Moral Authority; Palgrave Macmillan: Newcastle, UK, 2016; ISBN 978-1-137-56270-8.

31. Covey, S.R. The 8th Habit: From Effectiveness to Greatness; Free Press: New York, NY, USA, 2004.

32. Sabherwal, A.; Ballew, M.; Linden, S. The Greta Thunberg Effect: Familiarity with Greta Thunberg predicts intentions to engage in climate activism in the United States. Sage J. 2021, 1, 13. [CrossRef]

33. Goethals, G.; Sorenson, J. The Quest for a General Theory of Leadership; Edward Elgar Publishing: Cheltenham, UK, 2007.

34. Northouse, P. Leadership Theory and Practice; Sage Publication Ltd.: Los Angeles, CA, USA, 2001.

35. Srour, C.; Kheir-El-Din, A.; Samir, Y.M. The Effect of Green Transformational Leadership on Organizational Citizenchip Behavior in Egypt. Acad. J. Interdiscip. Stud. 2020, 9, 1. [CrossRef]

36. Hay, R. The Relevance of ecocentrism, personal development and transformational leadership to sustainability and identity. Sustain. Dev. 2010, 18, 163-171. [CrossRef]

37. Kura, K. Linking Environmentally Specific Transformational Leadership and Environmental Concern to Green Behavior Work. Glob. Bus. Rev. 2016, 17, 1S-14S. [CrossRef]

38. Hanbing, Z.; Maolin, Y. A Literature Review on Self-Sacrifical Leadership. Psychology 2016, 7, 1205-1210. [CrossRef]

39. Bengtsson, M. How to plan and perform a qualitative study using content analysis. Nurs. Open 2016, 2, 8-14. [CrossRef]

40. Ouzanni, M.; Hammady, H.; Fedorowicz, Y.; Elmagarmid, A. Prisma-A web and mobile app for systematic reviews. Syst. Rev. 2016, 5, 201-210. [CrossRef]

41. Clark, K.; Duckham, M.; Guillemin, M.; Hunter, A.; McVernon, J.; O'Keefe, C.; Waycott, J. Guidelines for the Ethical Use of Digital Data in Human Research; The University of Melbourne: Melbourne, Australia, 2015.

42. Lubke, J.; Britt, V.; Paulus, T.; Atkins, D. Hacking the Literature Review: Opportunities and Innovations to Improve the Research Process. Ref. User Serv. Q. 2017, 56, 285-295. [CrossRef]

43. Robson, C. Real World Research; Blackwell Publishing: Oxford, UK, 2008. 
44. Burles, M.; Bally, J. Ethical, Practical, and Methodological Considerations for Unobtrusive Qualitative Research About Personal Narratives Shared on the Internet. Int. J. Qual. Methods 2018, 17, 1609406918788203. [CrossRef]

45. Milman, O. Greta Thunberg condemns world leaders in emotional speech at UN. The Guardian. Available online: https: //www.theguardian.com/environment/2019/sep/23/greta-thunberg-speech-un-2019-address (accessed on 8 January 2021).

46. Oscarson, S. Svårt val: Två sätt att rädda Jorden. Svenska Dagbladet. Available online: https://www.svd.se/svart-val-tva-satt-attradda-jorden (accessed on 5 March 2021).

47. Williams, K.J. There's another Mardi Gras pastry with the lore of king. Sweden is where you'll find it. Washington Post. Available online: https:/ / www.washingtonpost.com/-mardi-gras-bun\%2f (accessed on 16 February 2021).

48. Karlsson, E. Greta Thunberg om diagnosen och bronsstatyn. Aftonbladet. Available online: https://www.aftonbladet.se/nyheter/ a/7KR28V/greta-thunberg-om-diagnosen-och-bronsstatyn (accessed on 16 March 2021).

49. Show, D. Climate Scientists say Greta Thunberg's efforts are building real momentum. Fox News. Available online: https: //www.foxnews.com/science/5-inconvenient-truths-about-the-climate-strike (accessed on 8 January 2021).

50. The Local, Greta Thunberg slams leader's “empty words" ahead of Paris anniversary. The Local. Available online: https:/ /www. thelocal.se/20201212/greta-thunberg-condemns-empty-words-ahead-of-paris-anniversary/ (accessed on 8 January 2021).

51. Thomas, G.; Cretney, R.; Ernman, M. Student Strike 4 Climate: Justice, emergency and citizenship. Sage J. 2019, 4, 96-100. [CrossRef]

52. Rowlatt, J. No COVID Confidential: Greta Thunberg. BBC News. Available online: https://www.bbc.com/news/scienceenvironment-53100800 (accessed on 12 January 2021).

53. The Local, Movie shows new sides of Swedish Climate activist Greta Thunberg. The Local. Available online: https://www. thelocal.se/20200904/movie-shows-new-sides-of-swedish-climate-activist-greta-thunberg/ (accessed on 15 January 2021).

54. Vlessing, E. Toronto: Greta Thunberg Calls Out Celebrity Culture as "Absurd". Available online: https:/ / www.hollywoodreporter. $\mathrm{com} /$ news/general-news/toronto-greta-thunberg-calls-out-celebrity-culture-as-absurd-4063341/\#! (accessed on 6 January 2021).

55. Mastrangelo, D. Greta Thunberg Presses Biden Administration to 'Treat Climate Crisis Like a Crisis'. Available online: https:/ / www.msn.com/en-xl/northamerica/northamerica-top-stories / greta-thunberg-presses-biden-administration-totreat-climate-crisis-like-a-crisis/ar-BB1eqi8s (accessed on 19 June 2021).

56. Helmerson, E. Greta Thunberg: Ni säger att ni rapporterar om klimatkrisen-Men det gör ni inte. Dagens Nyheter. Available online: https: / / www.dn.se/kultur/greta-thunberg-ni-sager-att-ni-rapporterar-om-klimatkrisen-men-det-gor-ni-inte/ (accessed on 6 January 2021).

57. Monnappa, C.; Jain, R. Greta Thunberg shares 'toolkit'to help India's farmers: India arrests local climate activist. Vancouver Sun. Available online: https:/ / vancouversun.com/category/news/world/?iframe=true\&preview=true\&theme_preview=true\%2F201 2\%2F03\%2F05\%2Fpage\%2F2\%3Fiframe\%3Dtrue\&from=1075 (accessed on 6 January 2021).

58. Chomsky, N.; Pollin, R. The Political Economy of Saving the Planet. Boston Review. Available online: https://bostonreview. net/science-nature-global-justice/noam-chomsky-robert-pollin-c-j-polychroniou-political-economy-saving (accessed on 18 January 2021).

59. Isserow, J.; Klein, C. Hypocrisy and Moral Authority. J. Ethics Soc. Philos. 2017, 12, 264-291. [CrossRef]

60. Röstlund, L. Psykologer vädjar till regeringen om barns klimatångest. Dagens Nyheter. Available online: https://www.dn.se/ sverige/psykologer-vadjar-till-regeringen-om-barns-klimatangest/ (accessed on 3 January 2021).

61. Sridham, D.V. Greta Thunberg is more concerned with blame than solutions. BBC News. Available online: https://www.bbcnews. com/2019/08/02/opinion/climate-change-greta-thunberg.html (accessed on 9 February 2021).

62. Timsit, A. "Act as if you loved your children above all else": Greta Thunberg speaks at Davos. QUARTZ. Available online: https:/ / qz.com/1788411/greta-thunberg-speaks-at-davos-our-house-is-still-on-fire/ (accessed on 3 January 2021).

63. Zraick, K. Greta Thunberg, After Pointed U.N. Speech, Faces Attacks from the Right. New York Times. Available online: https:/ / www.nytimes.com/2019/09/24/climate/greta-thunberg-un.html (accessed on 3 January 2021).

64. Grönberg, A. Thunberg: Vi lever i Förnekelse. Svenska Dagbladet. Available online: https://www.svd.se/thunberg-vi-lever-ifornekelse (accessed on 3 January 2021).

65. Blitzer, R. Climate activist Greta Thunberg, 16, tells House committees: "Unite behind the science" and "take real action". Fox News. Available online: https://www.foxnews.com/politics/climate-activist-greta-thunberg-tells-house-committees-to-unitebehind-the-science-and-take-real-action (accessed on 17 February 2021).

66. Grossman, N. I Huvudet på Greta Thunberg. Aftonbladet. Available online: https://www.aftonbladet.se/nojesbladet/a/jBvr6b/ihuvudet-pa-greta-thunberg (accessed on 2 January 2021).

67. Harvey, F. Greta Thunberg and children's group hit back at attempt to throw out climate case. The Guardian. Available online: https:/ / www.theguardian.com/environment/2020/may/05/greta-thunberg-and-childrens-group-hit-back-at-attemptto-throw-out-climate-case (accessed on 19 January 2021).

68. Adams, D. Psychology for Peace Activists: A New Psychology for the Generation Who Can Abolish War; Springer: New York, NY, USA, 1995.

69. Wallace, D. Greta Thunberg apologizes for "against the wall" remark, plans a break from climate activism. Fox News. Available online: https: / / www.foxnews.com/world/greta-thunberg-apologizes-against-the-wall-break-global-activism-time-personof-year (accessed on 3 January 2021). 
70. Carlqvist, F. Thunbergs Hårda Klimatkritik: "Vakna upp". Aftonbladet. Available online: https://www.aftonbladet.se/nyheter/ a/OQQbmE/thunbergs-harda-klimatkritik-vakna-upp (accessed on 18 January 2021).

71. Ford, N. Teen activist says future has been stolen by climate change. Fox News. Available online: https://www.foxnews.com/ teen-activist-future-stolen-climate-change-62576710 (accessed on 3 January 2021).

72. Wu, J.; Snell, G.; Samji, H. Climate anxiety in young people: A call to action. Lancet Planet. Heal. 2020, 4, 27-61. [CrossRef]

73. Ruiz, M. Greta Thunberg awarded \$1.15 M Gulbenkian Prize for Humanity, will donate to climate groups. Fox News. Available online: https:/ / www.foxnews.com/world/greta-thunberg-awarded-gulbenkian-prize-for-humanity-donate-climate-groups (accessed on 14 January 2021).

74. Winman, B. Där man bränner bilder släcks också liv. Dagens Nyheter. Available online: https://www.dn.se/kultur/bjorn-wimandar-man-branner-bilder-slacks-ocksa-liv / (accessed on 3 January 2021).

75. Hallett, V. Teen activist Greta Thunberg is now a fashion icon, whether she likes it or not. Washington Post. Available online: https:/ / www.washingtonpost.com/teen-activist-greta-thunberg-is-now-a-fashion-icon-whether-she-likes-it-or-not $\% 2$ f2 020\%2f04\%2f13\%2f833ce1fe-6d33-11ea-aa80-c2470c6b2034_story (accessed on 8 January 2021).

76. Forsberg, B. Nya Uppdraget: Lönsam Klimatomställning. Svenska Dagbladet. Available online: https://www.svd.se/nyauppdraget-lonsam-klimatomstallning (accessed on 3 January 2021).

77. Payne, P.G. Environmental education, democracy, Thunberg and XR. Polit. Q. 2021, 1, 307-348. [CrossRef]

78. Boucher, E. The dangers of depicting Greta Thunberg as a prophet. QUARTZ. Available online: https://qz.com/1769727/thedangers-of-depicting-greta-thunberg-as-a-prophet/ (accessed on 3 January 2021).

79. Roberts, J.T.; Parks, B. A Climate of Injustice: Global Inequality, North-South Politics, and Climate Policy; MIT Press: Cambridge, MA, USA, 2007.

80. Dalal, N. Today's biggest threat to democracy isn't fake news-It's selective facts. QUARTZ. Available online: https://qz.com/ 1130094/todays-biggest-threat-to-democracy-isnt-fake-news-its-selective-facts / (accessed on 20 February 2021).

81. Näslund, L. Jag försöker bryta genom att säga till pappa att inte slå. Dagens Nyheter. Available online: https://www.dn.se/ sverige/jag-forsokte-bryta-genom-att-saga-till-pappa-att-inte-sla/ (accessed on 3 January 2021).

82. Lynch, J. When Anger Scares You: How to Overcome Your Fears; New Harbin: Oakland, CA, USA, 2004.

83. Vertigan, A.; Nelon, C. Why angry middle-aged men are so threatened by Greta Thunberg. QUARTZ. Available online: https: / / finance.yahoo.com/news/why-angry-middle-aged-men-143058884.html (accessed on 4 February 2021).

84. Dongwon, Y.; Heajung, J.; Kelly, A. Dimensions of Leader Anger Expression Unveiled: How Anger Intensity and Gender of Leader and Observer Affect Perception of Leadership Effectiveness and Status Conferral. Front. Psychol. 2015, 11, 50. [CrossRef]

85. Caldwell, C. The Problem With Greta Thunberg's Climate Activism. New York Times. Available online: https://www.nytimes. com/2019/08/02/opinion/climate-change-greta-thunberg.html (accessed on 3 January 2021).

86. Raven, B.H.; French, J. The Bases of Social Power. MI Inst. Soc. Res. 1959, 6, 150-167.

87. Swedish Public Health Agency Miljöhälsorapport. Available online: https:/ / www.folkhalsomyndigheten.se/publicerat-material/ publikationsarkiv/m/miljohalsorapport-2021/?pub=88328 (accessed on 22 February 2021).

88. Plumwood, V. Environmental Culture: The Ecological Crisis of Reasoning; Routledge: New York, NY, USA, 2002.

89. Fielding, K.; Hornsey, M. Social Identity Analysis of Climate Change and Environmental Attitudes and Behaviors: Insights and Opportunities. Front. Psychol. 2016, 7, 37. [CrossRef] [PubMed]

90. D'Cruz, H.; Jones, M. Social Work Research: Ethical and Political Contexts; Sage Publications: London, UK, 2007. 